\title{
Pemanfaatan Dana Desa Berbasis Perkembangan dan Resiliensi Desa di Kabupaten Pandeglang Provinsi Banten
}

\author{
Village Funds Usage Based on Rural Development \\ and Rural Resilience in Pandeglang District, Banten Province
}

Siti Khoeriyah ${ }^{1}$, Ernan Rustiadi2 ${ }^{2}$ Akhmad F. Syam ${ }^{3}$

Diterima: 27 November 2018

Disetujui: 6 September 2019

\begin{abstract}
Abstrak: Penelitian ini bertujuan untuk memetakan tipologi desa berdasarkan status perkembangan dan status resilensi desa guna memberikan arahan dalam pemanfaatan dana desa. Status perkembangan desa dibangun dengan 13 indikator dan status resiliensi desa dibangun dengan 10 indikator. Penelitian menggunakan data sekunder dari BPS yaitu PODES Tahun 2014 sejumlah 326 desa di Kabupaten Pandeglang. Hasil penelitian menunjukkan bahwa berdasarkan status perkembangan terdapat 5 desa berstatus desa maju, 92 desa berstatus desa berkembang, 177 desa berstatus desa tertinggal, dan 52 desa berstatus desa sangat tertinggal. Berdasarkan status resiliensi terdapat 16 desa berstatus desa resiliensi rendah, 239 desa berstatus desa resiliensi sedang, dan 71 desa berstatus desa resiliensi tinggi. Berdasarkan status perkembangan dan resiliensi terdapat 4 desa masuk tipologi B (maju resiliensi sedang), 1 desa masuk tipologi $\mathrm{C}$ (maju resilensi rendah), 4 desa masuk tipologi $\mathrm{D}$ (berkembang resilensi tinggi), 79 desa masuk tipologi $\mathrm{E}$ (berkembang resiliensi sedang), 9 desa masuk tipologi $\mathrm{F}$ (berkembang resiliensi rendah), 35 desa masuk tipologi $\mathrm{G}$ (tertinggal resiliensi tinggi), 136 desa masuk tipologi $\mathrm{H}$ (tertinggal resiliensi sedang), 6 desa masuk tipologi I (tertinggal resiliensi rendah), 32 desa masuk tipologi J (sangat tertinggal resiliensi tinggi), dan 20 desa masuk tipologi $\mathrm{K}$ (sangat tertinggal resiliensi sedang).
\end{abstract}

Kata kunci: dana desa, tipologi desa, resiliensi

\begin{abstract}
This study aimed at map village typologies based on the status of rural development and resilience for prepare the guidance village funds usage. Status of rural development was built with 13 indicators and status resilience was built with 10 indicators. The study used secondary data from BPS, wich was PODES 2014 in 326 villages at Pandeglang district. The results showed that 5 villages were categorized as advanced villages, 93 villages were categorized as developed villages, 177 villages as undeveloped villages, and 52 were categorized as outlying villages. Based on resilience status, there were 16 villages categorized as low resilience villages, 239 villages as middle resilence villages, and 71 villages categorized as high resilience villages. Based on the status of development and resileince, 4 villages were categorized as typology B (advanced and middle resilience villages), 1 village were typology $\mathrm{C}$ (advanced and low resiliece villages), 4
\end{abstract}

\footnotetext{
${ }^{1}$ Program Studi Perencanaan Wilayah, Institut Pertanian Bogor

2 Program Studi Perencanaan Wilayah, Sekolah Pascasarjana, Departemen Ilmu Tanah dan Sumberdaya Lahan, Institut Pertanian Bogor

${ }^{3}$ Program Studi Perencanaan Wilayah dan Perdesaan, Fakultas Ekonomi dan Manajemen, Institut Pertanian Bogor
} 
villages were typology $\mathrm{D}$ (developed and high resilience villages), 79 villages were typology $\mathrm{E}$ (developed and middle resilience villages), 9 villages were typology $\mathrm{F}$ (developed and low resilience villages), 35 villages were typology $G$ (undeveloped and high resilience villages), 136 were typology $\mathrm{H}$ (undeveloped and middle resilience villages), 6 villages were typology I (undeveloped and low resilience villages), 32 villages were typology $\mathbf{J}$ (outlying and high resilience villages), and 20 villages were typology $\mathrm{K}$ (outlying and middle resilience villages).

Keywords: village funds, village typology, resilience

\section{PENDAHULUAN}

Pembangunan desa di Indonesia semakin digencarkan mendekati berakhirnya masa pemerintahan Jokowi - JK ditahun 2019. BPS (2018) menyebutkan jumlah desa di Indonesia mencapai 74.754 desa. Jika dibandingkan dengan jumlah kota provinsi, kota madya dan kota kabupaten di seluruh Indonesia yang hanya berjumlah sekitar 500 kota (Ihsan 2015) maka jumlah desa yang sangat besar menjadikan posisi desa sangat strategis untuk membangun sebuah negara, dan desa menjadi salah satu isu penting yang perlu diperhatikan secara serius (Sidik 2015) sebagai salah satu agenda prioritas nasional, karena desa merupakan kawasaan terkecil dari roda pemerintahan tempat sebagian besar penduduk miskin bermukim (Sartika et al. 2016). Keseriusan pemerintah atas pmbangunan desa dituangkan dalam Rencana Pembangunan Jangka Menengah Nasional (RPJMN) 2014-2019.

Program pembangunan desa yang semula hanya menjadi program tambahan dalam pembangunan nasional, namun pembangunan desa menemukan kembali momentumnya pada saat Presiden Jokowi mencanangkan sembilan agenda prioritas pembangunan yang disebut Nawa Cita. Cita ketiga menyebutkan bahwa membangun Indonesia dari pinggiran dengan memperkuat daerah-daerah dan desa dalam kerangka negara kesatuan. Kebijakan membangun dari desa merupakan suatu kebijakan yang baik dalam membangun secara umum suatu wilayah (Artino 2017). Keseriusan pemerintah untuk membangun dari pinggiran sejalan dengan Undang - undang nomor 6 tahun 2014 tentang Desa, dan salah satu bentuk nyata keseriusan pemerintah dalam membangun desa melalui suatu program yang disebut dana desa.

Sejauh mana pemanfaatan dana desa yang ada saat ini telah membawa pengaruh terhadap proses pengembangan desa suatu daerah dirasa perlu dikaji untuk mengetahui manfaat dari dana desa. Pandeglang sebagai salah satu Kabupaten penerima dana desa merupakan kabupaten yang potensial karena secara geografis terletak tidak jauh dari ibukota negara dan dikelilingi pula oleh pusat - pusat pengembangan, namun kondisi ini dirasa ironi dengan keadaan aktual kabupaten Pandeglang yang sampai saat ini masih masuk kategori kabupaten daerah tertinggal berdasarkan Peraturan Menteri Pembangunan Daerah Tertinggal nomor 78 tahun 2014. Selama tiga tahun terakhir persentase penduduk miskin di Kabupaten Pandeglang menjadi yang tertinggi, sedangkang laju pertumbuhan ekonomi kabupaten Pandeglang menjadi yang terendah jika di banding dengan kabupaten daerah tertinggal lainnya di provinsi Banten. Data IDM menunjukan lebih dari 65 persen desa di kabupaten Pandeglang dalam kategori tertinggal dan sangat tertinggal dan IPD Kabupaten Pandeglang menjadi yang terendah di banding tiga kabupaten lainnya di provinsi Banten. Berkaitan dengan hal tersebut penelitian ini bertujuan untuk (1) Menganalisis tipologi desa - desa di kabupaten Pandeglang berdasarkan status perkembangan dan status kelentingan/resiliensi desa, (2) Menyusun arahan rencana pemanfaatan dana desa bagi pengembangan desa di Kabupaten Pandeglang berdasarkan tipologi desa.

Pemetaan tipologi ini didasarkan pada klasifikasi wilayah berdasarkan indikator yang kemudian diidentifikasi karakteristik yang menonjol atau ketertinggalan (Muta'ali, 2014). Penelitian tentang tipologi desa juga pernah dilakukan oleh Yudha (2018), pentipologian desa di Pandeglang dilakukan dengan memodifikasi indikator kinerja 
pembangunan yaitu memodifikasi nilai indeks desa membangun dengan penyusunan kriteria indeks komposit yang spesifik meliputi fisik lingkungan dan infratruktur, sumber daya manusia dan kelembagaan serta ekonomi, dihasilkan 8 (delapan) tipologi desa di kabupaten Pandeglang yang meliputi tipologi A dimana kondisi fisik dan infrastruktur baik, kemasyarakatan dan kelembagaan baik, dan ekonomi baik, tipologi B dimana kondisi fisik dan infrastruktur baik, kemasyarakatan dan kelembagaan baik, dan ekonomi buruk, tipologi C dimana kondisi fisik dan infrastruktur baik, kemasyarakatan dan kelembagaan buruk, dan ekonomi baik, tipologi D dimana kondisi fisik dan infrastruktur buruk, kemasyarakatan dan kelembagaan baik, dan ekonomi baik, tipologi E dimana kondisi fisik dan infrastruktur baik, kemasyarakatan dan kelembagaan buruk, dan ekonomi buruk, tipologi $\mathrm{F}$ dimana kondisi fisik dan infrastruktur buruk, kemasyarakatan dan kelembagaan baik, dan ekonomi buruk, tipologi G dimana kondisi fisik dan infrastruktur buruk, kemasyarakatan dan kelembagaan buruk, dan ekonomi baik, tipologi $\mathrm{H}$ dimana kondisi fisik dan infrastruktur buruk, kemasyarakatan dan kelembagaan buruk dan ekonomi buruk. Pentipologian desa pernah dilakukan pula oleh Budiarto (2017) pada penelitiannya tentang tipologi desa di kabupaten Bogor didasarkan pada status perkembangan dan status kemandirian. Diperoleh hasil bahwa tipologi desa di kabupaten Bogor terdiri dari 4 (empat) tipologi desa di kabupaten Bogor yang meliputi: tipologi I merupakan desa maju dan mandiri, tipologi II merupakan desa maju tetapi tidak mandiri, tipologi III merupakan desa tertinggal dan mandiri, dan tipologi IV merupakan desa tertingga dan tidak mandiri.Yuningsih dan Subekti (2016) dalam penelitiannya mentipologikan desa di provinsi Jawa Barat 2008 - 2013 kaitannya dengan proses pemilihan kepala desa, menjadi 3 (tiga) tipologi desa yang meliputi: desa tradisional, desa transisional dan desa modern. Rahayu (2015) mentipologikan desa di kabupaten Pacitan sebagai dasar penentu prioritas pembangunan dengan menggunakan indikator demografi dan ketenagakerjaan, kondisi geografis, infrastruktur ekonomi, infrastruktur dan akses kesehatan serta pendidikan, terdapat 5 (lima) tipologi desa di Kabupaten Pacitan yaitu: desa dataran tinggi kurang maju dominan peternakan, desa dataran tinggi kurang maju potensial pertanian, desa kurang maju pertanian lemah, desa maju pertanian kuat, desa maju potensial pertanian. Syarif et al. (2014) melakukan metode yang sama yakni penggunaan tipologi desa dengan faktorfaktor dominan sebagai penentu tipologi objek kajiannya. Hasil penelitiannya menunjukkan bahwa pada desa objek kajian memiliki tipologi desa swasembada dengan ciri kehidupan masyarakat kota.

\section{METODE PENELITIAN}

Penelitian ini dilakukan pada aras mikro yakni skala desa. Lokasi yang ditentukan adalah Kabupaten Pandeglang Provinsi Banten dengan argumentasi bahwa Kabupaten Pandeglang letaknya tidak jauh dari ibukota Negara Jakarta namun masih masuk dalam kategori kabupaten daerah tertinggal menurut Permen PDT No 78 tahun 2014. Kabupaten Pandeglang berbatasan dengan kabupaten Lebak. Waktu penelitian dilakukan bulan Mei 2018 sampai dengan bulan Oktober 2018. Data yang diambil adalah data yang diperoleh dari data Badan Pusat Statistik yakni Potensi Desa tahun 2014. Penentuan tipologi desa dalam penelitian ini didasarkan pada status perkembangan desa dan status kelentingan/resiliensi desa, dimana dalam menetukan status perkembangan dan kelentingan desa dilakukan melalui analisis skoring dan tabulasi. Indikator yang terpilih yang mewakili indikator sosial, ekonomi dan ekologi lingkungan. Pemilihan analisis ini didasarkan pada penelitian sebelumnya Budiarto (2017), Junaedi (2012), dan Syarief et al. (2014).Indikator yang dipakai dalam penentuan status perkembangan desa, digunakan 13 indikator yang dianggap cukup mewakili komponen sosial, lingkungan, dan ekonomi. Kompenen sosial diwakili oleh lapangan usaha mayoritas penduduk, jarak desa dari ibukota kecamatan, fasilitas pendidikan, jumlah tenaga kesehatan, jumlah pesantren, komponen lingkungan diwakili oleh ketersediaan jamban rumah tangga, ketersediaan 
penampungan sampah, kepadatan penduduk $/ \mathrm{Km}^{2}$, sumber air bahan minum/memasak, sumber bahan bakar yang dipakai, sedangkan komponen ekonomi diwakili oleh ketersediaan angkutan umum, jumlah industri kecil mikro, dan ketersediaan pasar. Masing - masing indikator diberi skor sesuai dengan kondisi masing - masing desa yang kemudian masing - masing skor pada tiap desa dijumlahkan. Pembagian kelas perkembangan desa di cari dengan menetukan interval kelas terlebih dahulu dengan formula:

$$
\begin{aligned}
& \mathbf{C}=\frac{\mathbf{X n}-\mathbf{X i}}{\mathbf{k}} \\
& \mathrm{C}=\text { Interval kelas } \\
& \mathrm{Xn}=\text { Jumlah Skor Tertinggi } \\
& \mathrm{Xi}=\text { Jumlah Skor Terendah } \\
& \mathrm{k}=\text { jumlah kelas yang dikendaki }
\end{aligned}
$$

Didasarkan tipologi desa pada kabupaten Pandeglang, maka kelas tipologi desa (nilai k) ditetapkan empat, dengan mengetahui interval kelas sehingga dapat ditetapkan 4 (empat) tipologi desa yang meliputi desa maju, desa berkembang, desa tertinggal, dan desa sangat tertinggal.

Resiliensi desa merupakan kondisi yang berkebalikan dengan kerentanan, sehingga dengan menentukan tingkat kerentanan secara otomatis tingkat resiliensi desa akan dapat ditentukan. Pemilihan indikator dalam penelitian ini didasarkan pada Permen LHK nomor P.7/MENLHK/SETJEN/KUM.1/2/2018 (Kemen LHK 2018), penelitian Hidayati (2015) dan Yoo et.al (2014). Indikator yang digunakan dalam penentuan tingkat kerentanan digunakan 10 indikator yang mewakili tingkat keterpaparan (exposure), tingkat sesitivitas (sensitivity), dan tingkat kemampuan adaptasi (adaptive capasity). Tingkat keterpaparan diwakili oleh kepadatan penduduk, tingkat bencana alam, dan jumlah KK pemukiman kumuh. Tingkat sensitivitas diwakili oleh sumber air minum/masak, ketersediaan jamban, ketersediaan penampungan sampah, dan dependency rasio adalah jumlah penduduk yang tidak produkstif (usia $<14$ tahun dan $>65$ tahun), dan tingkat kemampuan adaptasi diwakili oleh jumlah KK tanpa listrik, jumlah warga penerima jaminan kesehatan desa (Jamkesda), dan jumlah industri kecil mikro. Masing - masing indikator dicari indeks dimensinya dengan formula:

$$
\begin{array}{ll}
\text { Indeks Dimensi }=\frac{\boldsymbol{X}-\boldsymbol{X}_{\min }}{\boldsymbol{X}_{\max }-\boldsymbol{X}_{\min }} \\
\begin{array}{ll}
\mathrm{X} & =\text { Nilai skor dari variabel yang diteliti } \\
\mathrm{X}_{\min } & =\text { Nilai skor terkecil dari varibel yang di teliti } \\
\mathrm{X}_{\max } & =\text { Nilai skor terbesar dari varibel yang di teliti }
\end{array}
\end{array}
$$

Setiap indeks indikator dijumlahkan sehingga membentuk indeks keterpaparan, indeks sensitivitas, dan indeks kemampuan adaptasi.

Setelah dilakukan perhitungan Nilai Indeks Keterpaparan (NIK), Nilai Indeks Sensitivitas (NIS) dan Nilai Indeks Kapasitas Adaptasi (NIKA) maka dilakukan perhitungan Indeks Kerentanan (IK). Formula Indeks Kerentanan (IK) sebagai berikut Yoo et al. (2014):

$$
\text { IK }=(\text { NIK + NIS })-\text { NIKA }
$$

$\begin{array}{ll}\text { Keterangan } & : \\ \text { IK } & : \text { Indeks Kerentanan } \\ \text { NIK } & : \text { Nilai Indeks Keterpaparan } \\ \text { NIS } & : \text { Nilai Indeks Sensitivitas } \\ \text { NIKA } & : \text { Nilai Indeks Kapasitas Adaptasi }\end{array}$


Jika nilai IK sudah diketahui, selanjutnya dilakukan reklasifikasi sehingga tingkat kerentanan dapat di ketahui. Reklasifikasi ini yakni dengan menentukan jumlah kelas dan interval kelas. Jumlah kelas kerentanan dibagi 3 tingkat meliputi tingkat kerentanan tinggi, sedang, dan rendah. Berdasarkan hasil dari kerentanan maka dapat di ditetapkan tingkat kelentingan/resiliensi desa kedalam 3 (tiga) kelas yakni desa dengan kelentingan rendah, desa dengan kelentingan sedang, dan desa dengan kelentingan tinggi.

Pemetaan tipologi desa dilakukan dengan tabulasi silang antara perkembangan desa dan resiliensi desa yang telah didapatkan pada hasil analisis sebelumnya. Penyusunan arahan pemanfaatan dana desa didasarkan pada Permendesa Nomor 19 tahun 2017 dan Permendesa Nomor 15 Tahun 2016 dengan berbasis pada tipologi desa yang diperoleh dari hasil analisis.

\section{HASIL DAN PEMBAHASAN}

\section{Status Perkembangan Desa di Kabupaten Pandeglang}

Status perkembangan desa ini merupakan suatu ukuran yang sengaja disusun untuk menilai bagaimana tingkat perubahan atau perkembangan desa khususnya di Kabupaten Pandeglang dengan unit analisanya desa. Pengukuran status perkembangan desa dibangun dari ketersediaan data hasil pendataan Potensi Desa (PODES) tahun 2014 yang telah dilaksanakan oleh Badan Pusat Statistik pada tahun 2014 dan dipakai sebagai rujukan indikator-indikator penyusunan status. Data PODES juga banyak dipakai untuk dijadikan sebagai rujukan pada penyusunan status yang lain sesuai kebutuhan dan instansi yang berkepentingan. Penyusunan status ini juga diharapkan mampu menjadi alat yang memberikan informasi bagi pemerintah atau pelaku pembangunan desa supaya dapat memberikan intervensi kebijakan yang tepat sasaran dan berkelanjutan. Selanjutnya, diharapkan juga mampu menjadi alat monitor dan evaluasi terhadap kinerja pembangunan desa dalam rangka pencapaian kinerja RPJMN 2015-2019.

Status perkembangan desa dibangun dengan 13 indikator sebagai bahan masukkannya. Indikator pertama lapangan usaha mayoritas penduduk desa di kabupaten Pandeglang sebanyak 318 desa atau 97,55 persen adalah sektor pertanian, sementara penduduk yang bekerja pada sektor indutri/kerajinan sebanyak 2 desa atau 0,63 . Indikator kedua terdapat 281 desa atau 86,19 persen yang jarak desa dengan ibukota kecamatannya di bawah $5 \mathrm{Km}$. Desa-desa yang jaraknya antara 6-9 $\mathrm{Km}$ dengan ibukota kecamatan terdapat 42 desa atau hanya 12,88 persen. Sedangkan desa-desa yang terjauh dari ibukota kecamatan atau melebihi dari $10 \mathrm{Km}$ jaraknya ada 3 desa atau sebesar 0,92 persen dari seluruh desa. Indikator ketiga terdapat 99 desa atau 30,36 persen yang hanya mempunyai fasilitas pendidikan berupa sarana bangunan sekolah dasar (SD), di tingkat sekolah lanjut pertama (SMP) ada 122 desa atau 37,42 persen. Desa yang memiliki fasilitas pendidikan di tingkat sekolah lanjut tingkat atas (SMA) ada 105 desa atau 32,21 persen. Indikator keempat desa yang memiliki fasilitas tenaga kesehatan minimal ada bidan sejumlah 140 desa atau 42,95 persen dari keseluruhan desa. Desa yang memiliki minimal ada tenaga paramedis sejumlah 130 desa atau 39,88 persen. Desa yang minimal mempunyai tenaga dokter sejumlah 31 desa atau 9,51 persen, sedangkan desa tanpa adanya tenaga kesehatan sejumlah 25 desa atau 7,67 persen. Indikator kelima desa yang memiliki pesantren sejumlah 78 desa atau 23,93 persen dari keseluruhan desa, sementara desa tanpa pesantren sejumlah 248 desa atau 76,07 persen.

Indikator keenam terdapat 143 desa atau 43,86 persen desa yang fasilitas jambannya bukan jamban. Bukan jamban di sini adalah belum mempunyai kakus yang tertutup untuk tempat pembuangan kotoran, untuk desa yang memiliki ketersediaan jamban bersama atau umum sejumlah 18 desa atau 5,52 persen dari total desa di Kabupaten Pandeglang, sedangkan desa-desa yang mayoritas penduduknya sudah memiliki jamban sendiri 
berjumlah 165 desa atau 50,61 persen. Indikator ketujuh total desa di Pandeglang tidak memiliki fasilitas penampungan sampah sehingga sampah dibuang di got, sungai atau dibuang di tanah terbuka sebanyak 201 desa atau 61,66 persen. Kemudian, desa-desa yang penampungan sampahnya berupa dikubur atau dibakar terdapat 115 desa atau 36,28 persen dari seluruh desa yang ada, sedangkan desa-desa yang sudah memiliki fasilitas baik mengenai penanganan sampah hanya ada 10 desa atau 3,07 persen. Indikator kedelapan terdapat desa yang memiliki kepadatan penduduk rendah yakni dari 0 (nol) hingga 200 jiwa/Km2 sejumlah 39 desa atau 11,69 persen, sedangkan desa yang kepadatan penduduknya antara 201-299 jiwa/Km2 sejumlah 19 desa atau 5,83 persen. Jumlah desa yang memiliki kepadatan penduduk di atas 300 jiwa/Km2 adalah 268 desa atau 87,37 persen. Indikator kesembilan mayoritas penduduk di Kabupaten Pandeglang menggunakan sumber air dari sumur atau perigi untuk memenuhi kebutuhan minum dan memasak yakni sebesar 57,7 persen atau sejumlah 177 desa. Desa-desa lain sebesar 18,4 persen atau 60 desa sudah menggunakan sumber air dari PAM atau pompa untuk mencukupi kebutuhan memasak dan minum. Sedangkan desa yang menggunakan sumber air hujan maupun sungai guna mencukupi kebutuhan memasak dan minum sejumlah 89 desa atau 27,3 persen. Indikator kesepuluh menunjukkan hasil bahwa 128 desa atau 39,26 persen penduduk di kabupaten Pandeglang menggunakan gas/listrik untuk sumber bahan bakar memasak, beberapa desa yang mayoritas penduduknya menggunakan bahan bakar kayu atau lainnya yakni sebesar 83,89 persen atau hanya 198 desa dari seluruh desa yang ada di kabupaten Pandeglang yang tetap menggunakan kayu bakar.

Indikator kesebelas desa-desa yang memiliki ketersediaan angkutan umum. Berdasarkan data tersebut terdapat 139 desa atau 42,64 persen yang tidak memiliki jaringan angkutan umum. Kemudian, sebanyak 90 desa atau 27,61 persen sudah memiliki atau dilalui oleh angkutan umum, namun tidak memiliki trayek tetap. Data desa yang sudah mempunyai ketersediaan angkutan umum dan memiliki trayek tetap terdapat 97 desa atau 29,5 persen. Indikator keduabelas jumlah industri kecil dibawah 200 unit ada pada 307 desa atau 94,17 persen. Jumlah industri kecil mikro antara 201 - 399 unit ada pada 15 desa atau 4,6 persen, sedangkan desa dengan jumlah kecil mikro diatas 400 unit ada pada 4 desa atau 1,23 persen. Indikator ketigabelas jumlah desa di kabupaten Pandeglang yang tersedia pasar sejumlah 36 desa atau 11,04 persen, sementara jumlah desa tanpa ketersediaan pasar sejumlah 290 desa atau 88,96 persen.

Pada hasil analisis perhitungan tabulasi dan skoring status perkembangan desa di Kabupaten Pandeglang terdapat 4 tipologi desa dengan jumlah desa maju sebanyak 5 desa atau 1,53\%, desa berkembang 92 desa atau $18,22 \%$, desa tertinggal 177 desa atau $54,29 \%$ dan desa sangat tertinggal 52 desa atau 15,95\%.

Tabel 1. Frekuensi desa berdasarkan status perkembangan desa di Kabupaten Pandeglang

\begin{tabular}{lcc}
\hline Status perkembangan desa & Frekuensi & Persentase \\
\hline Maju & 5 & $1,53 \%$ \\
Berkembang & 92 & $18,22 \%$ \\
Tertinggal & 177 & $54,29 \%$ \\
Sangat Tertinggal & 52 & $15,95 \%$ \\
Total & 326 & $100 \%$ \\
\hline
\end{tabular}

Sumber: Data Diolah, 2018

\section{Status Kelentingan/ Resiliensi Desa di Kabupaten Pandeglang}

Konsep resiliensi merupakan konsep yang luas, didalamnya termasuk kapasitas dan kemampuan merespon dalam situasi krisis/darurat sebagai akibat dari perubahan sosial, politik, dan lingkungan. Konsep dari resiliensi perdesaan menentukan sejauhmana daerah perdesaan tertentu mampu mentorerir perubahan. Resiliensi atau kelentingan desa dapat dilihat dari seberapa rentan suatu desa terhadap bencana yang terjadi. Kerentanan sering digambarkan sebagai kondisi yang berlawanan dengan kelentingan, jika suatu desa 
memiliki kerentanan yang tinggi berarti pula desa tersebut memiliki kelentingan yang rendah. Sebaliknya jika suatu desa memiliki kerentanan yang rendah berarti desa tersebut memiliki kelentingan yang tinggi.

Menentukan status kelentingan desa, terlebih dahulu menentukan tingkat kerentanan, karena kelentingan desa merupakan kondisi yang berkebalikan dengan kerentanan, sehingga dengan menentukan tingkat kerentanan secara otomatis tingkat kelentingan desa akan dapat ditentukan. Indikator yang digunakan untuk menentukan tingkat kerentanan desa adalah indikator yang mewakili tingkat keterpaparan (exposure) yaitu seberapa besar tingkat keterpaparan desa terhadap gangguan eksternal yang ada, tingkat sensitivitas atau kepekaan (sensitivity) yaitu derajat kepekaan atau sensitivitas desa terhadap gangguan dari luar (gangguan eksternal) yang akan mempengaruhi tingkat kerentanan dari suatu desa, dan tingkat kapasitas adaptasi (adaptive capacity) derajat dimana desa mampu beradaptasi dan memiliki sumberdaya untuk beradaptasi ketika terjadi gangguan dari luar.

Tingkat keterpaparan (exposure) dalam penelitian ini diwakili oleh indikator kepadatan penduduk, tingkat bencana alam, dan jumlah KK pemukiman kumuh. Desa yang memiliki kepadatan penduduk rendah yakni dari 0 (nol) hingga 200 jiwa/Km2 sejumlah 39 desa atau 11,69 persen, sedangkan desa yang kepadatan penduduknya antara 201-299 jiwa/Km2 sejumlah 19 desa atau 5,83 persen. Jumlah desa yang memiliki kepadatan penduduk di atas 300 jiwa/Km2 adalah 268 desa atau 87,37 persen. Frekuensi kejadian bencana alam di kabupaten pandeglang dengan jumlah kejadian di bawah 2 kali dalam setahun terdapat pada 294 desa atau 90,18 persen, sedangkan kejadian bencana alam yanga terjadi 3 sampai 4 kali setahun terdapat pada 25 desa atau 7,67 persen. Jumlah kejadian bencana alam diatas 5 kali per tahun terjadi di 7 desa atau 2,15 persen. jumlah desa dengan jumlah KK yang tinggal di pemukiman kumuh diatas $200 \mathrm{KK}$ sejumlah 4 desa atau 1,23 persen. Jumlah desa dengan jumlah KK yang tinggal di pemukiman kumuh antara $101-199 \mathrm{KK}$ sejumlah 8 desa atau 2,45 persen, sementara desa dengan jumlah KK yang tinggal dipemukiman kumuh dibawah $100 \mathrm{KK}$ berjumlah 314 desa atau 96,31 persen dari total seluruh desa yang ada di Pandeglang.

Tingkat sensitivitas (sensitivity) diwakili oleh sumber air minum/masak, ketersediaan jamban, ketersediaan penampungan sampah, dan dependency rasio adalah jumlah penduduk yang tidak produktif (usia $<14$ tahun dan $>65$ tahun). Desa dengan sumber air minum dari sumur, hujan dan lainnya ada 9 desa atau 2,76 persen. Jumlah desa dengan sumber air minum dari PAM/pompa listrik/pompa sejumlah 51 desa atau 15,64 persen dan jumlah desa dengan sumber air minum dari gallon atau isi ulang sejumlah 266 desa atau 81,59 persen. Desa-desa yang mayoritas penduduknya sudah memiliki jamban sendiri berjumlah 165 desa atau 50,61 persen. Jumlah desa dengan ketersediaan jamban umum/bersama sejumlah 143 desa atau 43,87 persen, sedangkan jumlah desa dengan fasilitas bukan jamban sejumlah 18 desa atau 5,52 persen. Desa-desa yang sudah memiliki fasilitas baik mengenai penanganan sampah hanya ada 10 desa atau 3,07 persen dari total keseluruhan desa yang ada di wilayah Kabupaten Pandeglang. Kemudian, desa-desa yang penampungan sampahnya berupa dikubur atau dibakar terdapat 115 desa atau 36,28 persen dari seluruh desa yang ada, sementara desa - desa di kabupaten Pandeglang lebih dari setengah dari total desa di Pandeglang tidak memiliki fasilitas penampungan sampah sehingga sampah dibuang di got, sungai atau dibuang di tanah terbuka sebanyak 201 desa atau 61,66 persen. Jumlah penduduk tidak produktif dibawah 1500 jiwa berjumlah 242 desa atau 74,23 persen. Desa dengan jumlah penduduk tidak produktif anatara $1501-3000$ jiwa berjumlah 77 desa atau 23,62 persen, sedangkan desa dengan jumlah penduduk tidak produktif diatas 3000 jiwa berjumlah 7 desa atau 2,15 persen dari total seluruh desa di kabupaten Pandeglang.

Tingkat kapasitas adaptasi (adaptive capacity) diwakili oleh jumlah KK tanpa listrik, jumlah warga penerima jaminan kesehatan desa (Jamkesda), dan jumlah industri kecil 
mikro. Desa dengan jumlah KK tanpa listrik dibawah $200 \mathrm{KK}$ sejumlah 316 desa atau 96,73 persen. Desa dengan jumlah KK tanpa listrik anatara $201-400 \mathrm{KK}$ ada 7 desa atau 2,15 persen dan desa dengan jumlah KK tanpa listrik diatas $400 \mathrm{KK}$ sejumlah 3 desa atau 0,92 persen. Jumlah desa dengan warga penerima jamkesda dibawah 1400 jiwa sejumlah 208 desa atau 63,80 persen. Jumlah desa dengan warga penerima jamkesda antara 1401 samapi 2800 jiwa sejumlah 105 desa atau 32,81 persen, sementara jumlah desa dengan warga penerima jamkesda diatas 2800 jiwa sejumlah 13 desa atau 3,99 persen. Jumlah industri kecil dibawah 200 unit ada pada 307 desa atau 94,17 persen. Jumlah industri kecil mikro antara 201 - 399 unit ada pada 15 desa atau 4,6 persen, sedangkan desa dengan jumlah kecil mikro diatas 400 unit ada pada 4 desa atau 1,23 persen dari total seluruh desa di kabupaten Pandeglang.

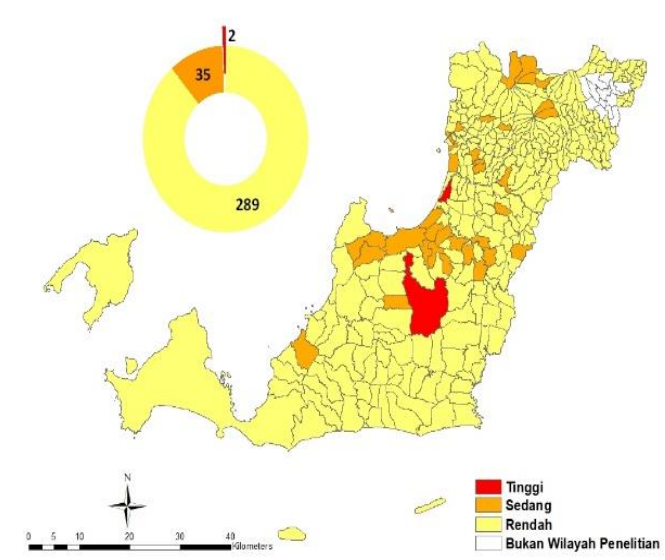

Tingkat Keterpaparan

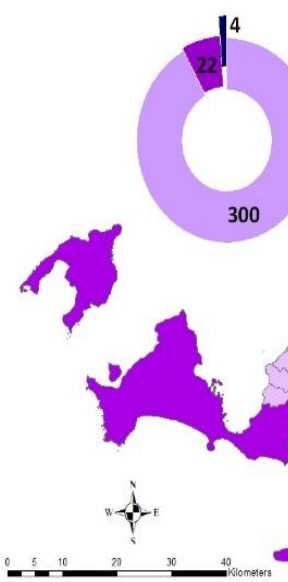

Tingkat Kemampuan Adaptasi

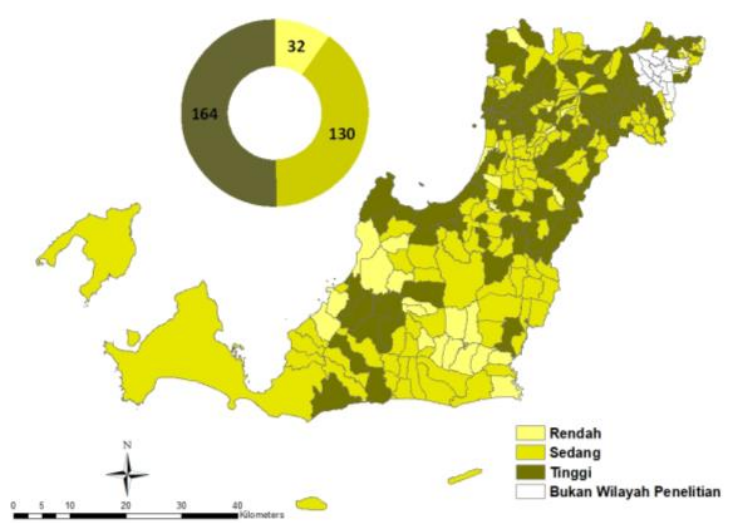

Tingkat Sensitivitas

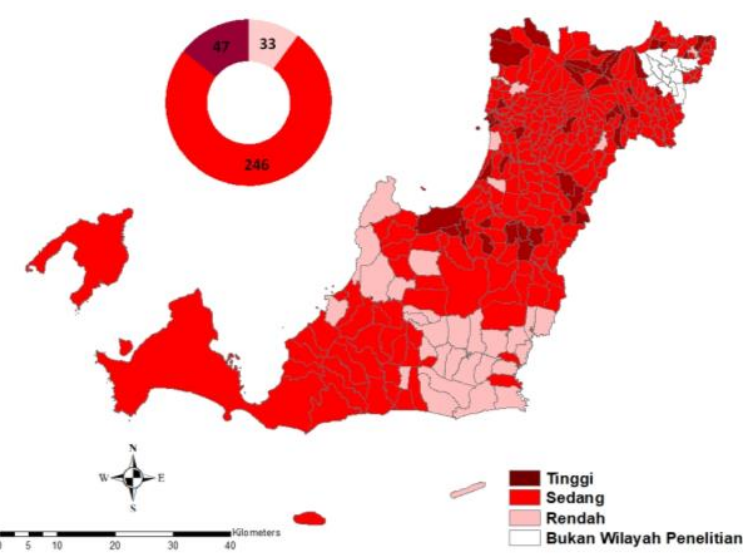

Tingkat Kerentanan

\section{Gambar 1. Peta Sebaran Tingkat Keterpaparan, Tingkat Sensitivitas, Tingkat Kemampuan Adaptasi, dan Tingkat Kerentanan di Kabupaten Pandeglang}

Berdasarkan hasil analisis keterpaparan (exposure) sensitivitas (sensitivity), dan kemampuan adaptasi (adaptive capability) jumlah desa dengan tingkat keterpaparan rendah sebanyak 289 desa atau 88,65\%, desa dengan tingkat keterpaparan sedang sebanyak 35 desa atau 10,74\% dan desa dengan tingkat keterpaparan tinggi sebanyak 2 desa atau $0,61 \%$, sementara jumlah desa dengan tingkat sensitivitas rendah 32 desa atau 9,82\%, desa dengan tingkat sensitivitas sedang 130 desa atau 42,38\% dan desa dengan tingkat sensitivitas tinggi 164 desa atau 50,30\% dan jumlah desa dengan tingkat kemampuan 
adaptasi rendah 300 desa atau 92,03\%, desa dengan tingkat kemampuan adaptasi sedang 22 desa atau 6,75\%, dan desa dengan tingkat kemampuan adaptasi tinggi 4 desa atau $1,23 \%$. Setelah dilakukan analisis keterpaparan, analisis sensitivitas dan analisis kapasitas adaptasi, maka langkah terakhir untuk mendapatkan tingkat kerentanan adalah dengan menghitung indeks kerentanan. Indeks Kerentanan merupakan hasil pengurangan indeks kapasitas adaptif terhadap penjumlahan keterpaparan dan sensitivitas. Terdapat 3 kategori tingkat kerentanan desa di Kabupaten Pandeglang yaitu tingkat kerentanan rendah terdiri dari 33 desa atau 10,12\%, tingkat kerentanan sedang sebanyak 246 desa atau 75,46\%, dan tingkat kerentanan tinggi sebanyak 47 desa atau $14,42 \%$. Peta sebaran tingkat keterpaparan, tingkat sensitivitas, tingkat kemampuan adapatasi, dan tingkat kerentanan di Kabupaten Pandeglang disajikan pada gambar 1.

Kelentingan atau resiliensi merupakan kondisi yang berlawanan dengan kerentanan, sehingga dengan mengetahui tingkat kerentanan desa secara otomatis tingkat kelentingan atau resiliensi desa di Kabupaten Pandeglang dapat ditentukan dengan tiga kategori yaitu tingkat kelentingan desa rendah, sedang dan tinggi. Jumlah desa dengan tingkat kelentingan atau resiliensi rendah sebanyak 47 desa atau 14,42 persen, jumlah desa dengan tingkat kelentingan atau resiliensi sedang sejumlah 246 desa aau 75,46 persen, dan jumlah desa dengan tingkat kelentingan atau resiliensi tinggi sejumlah 33 desa atau 10,12 persen. Peta status perkembangan dan status kelentingan/resiliensi desa disajikan pada gambar 2 .

Tabel 2 Frekuensi Desa Berdasarkan Tingkat Kelentingan atau Resiliensi Desa di Kabupaten Pandeglang

\begin{tabular}{lll}
\hline Tingkat Kelentingan/Resiliensi & Frekuensi & Persenta \\
& & se \\
\hline Rendah & 47 & $14,42 \%$ \\
Sedang & 246 & $75,46 \%$ \\
Tinggi & 33 & $10,12 \%$ \\
Total & 326 & $100 \%$ \\
\hline
\end{tabular}

Sumber : Data diolah, 2018

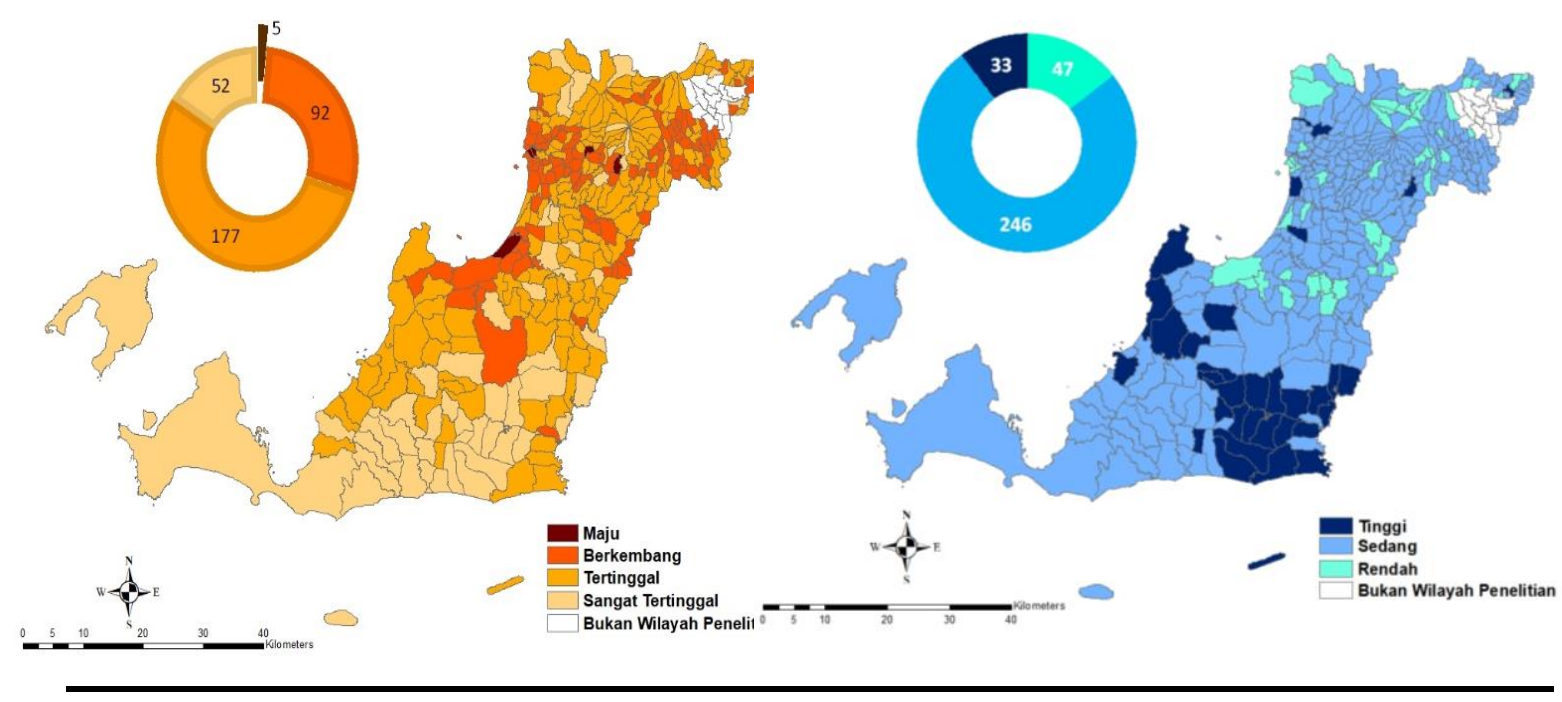

Gambar 2. Peta Status Perkembangan dan Status Kelentingan/Resiliensi Desa 


\section{Tipologi Desa di Kabupaten Pandeglang}

Tipologi desa disusun berdasarkan perolehan hasil dari penghitungan status perkembangan dan status kelentingan atau resiliensi desa. Kedua hasil tersebut, kemudian di "overlay" atau disajikan secara irisan dengan spasial dalam wujud peta sebaran yang disajikan pada gambar 3. Hasil analisis tipologi diperoleh 10 (sepuluh) tipologi desa di Kabupaten Pandeglang. Karekteristik tipologi desa disajikan pada tabel 4.

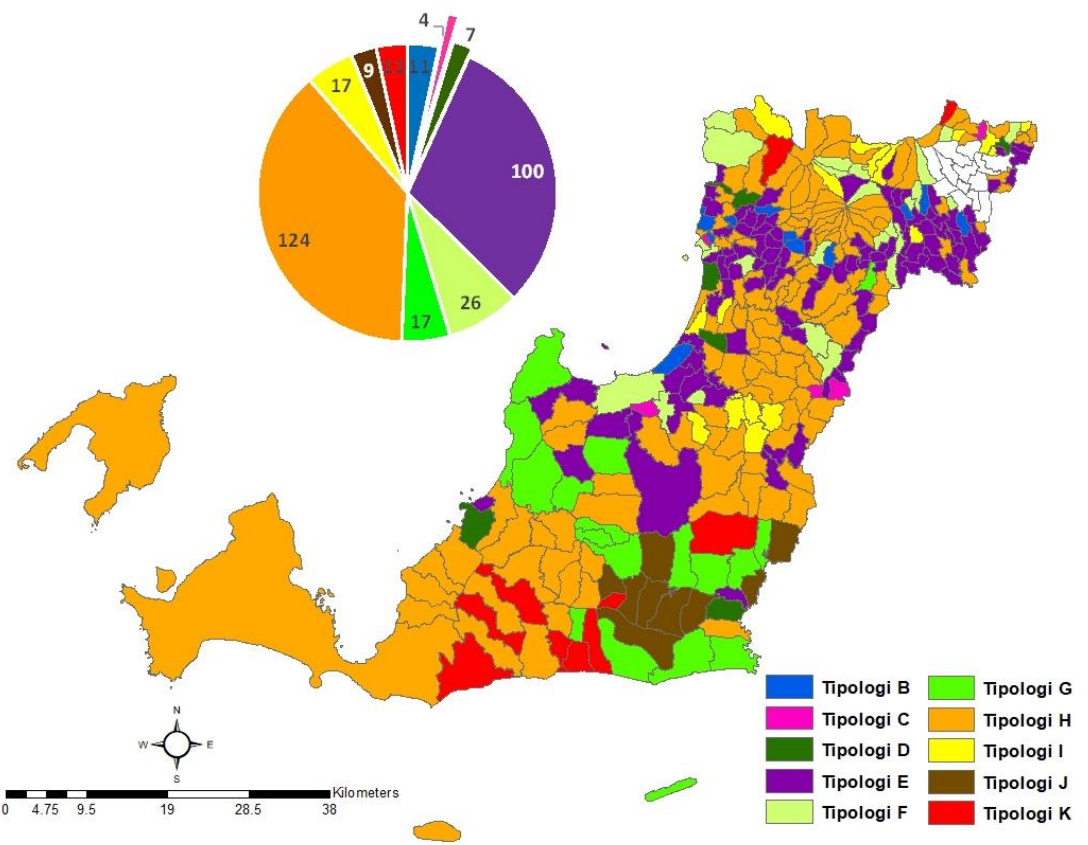

Gambar 3. Peta Tipologi Desa di Kabupaten Pandeglang

Tabel 4 Frekuensi Desa Berdasarkan Tingkat Perkembangan Desa dan Kelentingan/Resiliensi Desa di Kabupaten Pandeglang

\begin{tabular}{llrr}
\hline Tipologi Desa & Keterangan & Frekuensi & Persentase \\
\hline Tipologi B & Desa Maju Resiliensi Sedang & 11 & $33,37 \%$ \\
Tipologi C & Desa Maju Resiliensi Rendah & 4 & $1,23 \%$ \\
Tipologi D & Desa Berkembang Resiliensi Tinggi & 7 & $2,15 \%$ \\
Tipologi E & Desa Berkembang Resiliensi Sedang & 100 & $30,67 \%$ \\
Tipologi F & Desa Berkembang Resiliensi Rendah & 26 & $7,89 \%$ \\
Tipologi G & Desa Tertinggal Resiliensi Tinggi & 17 & $5,21 \%$ \\
Tipologi H & Desa Tertinggal Resiliensi Sedang & 124 & $38,24 \%$ \\
Tipologi I & Desa Tertinggal Resiliensi Rendah & 17 & $5,21 \%$ \\
Tipologi J & Desa Sangat Tertinggal Resiliensi Tinggi & 9 & $2,76 \%$ \\
Tipologi K & Desa Sangat Tertinggal Resiliensi Sedang & 11 & $3,37 \%$ \\
Total & & 326 & $100 \%$ \\
\hline
\end{tabular}

\section{Arahan Rencana Pemanfaatan Dana Desa Bagi Pengembangan Desa di Kabupaten Pandeglang} Berbasis Tipologi Desa

Berdasarkan tipologi desa di kabupaten Pandeglang maka dalam upaya pengembangan desa disusun arahan pemanfaatan dana desa dengan didasarkan pada Permendesa nomor 21 tahun 2015 tentang Penetapan Prioritas Penggunaan Dana Desa Tahun 2016 (Kemendesa 2015) dan Permendesa nomor 19 Tahun 2017 tentang Penetapan Prioritas Penggunaan Dana Desa tahun 2018 (Kemendesa 2017) disajikan pada tabel 5. 
Tabel 5 Arahan Rencana Pemanfaatan Dana Desa Bagi Pengembangan Desa Berdasarkan Tipologi Desa di Kabupaten Pandeglang

\begin{tabular}{|c|c|}
\hline Tipologi Desa & Karakteristik \\
\hline $\begin{array}{l}\text { Tipologi B } \\
\text { (Maju- } \\
\text { sedang) }\end{array}$ & $\begin{array}{l}\text { Kondisi } \\
\text { infrastruktur yang } \\
\text { baik dengan } \\
\text { kondisi } \\
\text { kelentingan sedang }\end{array}$ \\
\hline $\begin{array}{l}\text { Tipologi C } \\
\text { (Maju }- \\
\text { rendah) }\end{array}$ & $\begin{array}{l}\text { Kondisi } \\
\text { infrastruktur yang } \\
\text { sudah baik, namun } \\
\text { kondisi } \\
\text { kelentingan } \\
\text { rendah. }\end{array}$ \\
\hline $\begin{array}{l}\text { Tipologi D } \\
\text { (Berkembang- } \\
\text { Resiliensi tinggi) }\end{array}$ & $\begin{array}{l}\text { Kondisi } \\
\text { infrastruktur yang } \\
\text { cukup baik dan } \\
\text { kondisi } \\
\text { kelentingan tinggi. }\end{array}$ \\
\hline $\begin{array}{l}\text { Tipologi E } \\
\text { (Berkembang- } \\
\text { Resilensi sedang) }\end{array}$ & $\begin{array}{l}\text { Kondisi } \\
\text { infrastruktur yang } \\
\text { cukup baik dengan } \\
\text { kondisi } \\
\text { kelentingan } \\
\text { sedang. }\end{array}$ \\
\hline $\begin{array}{l}\text { Tipologi F } \\
\text { (Berkembang- } \\
\text { Resiliensi rendah) }\end{array}$ & $\begin{array}{l}\text { Kondisi } \\
\text { infrastruktur yang } \\
\text { cukup baik, } \\
\text { namun kondisi } \\
\text { kelentingan } \\
\text { rendah. }\end{array}$ \\
\hline $\begin{array}{l}\text { Tipologi G } \\
\text { (Tertinggal-Resiliensi } \\
\text { tinggi) }\end{array}$ & $\begin{array}{lr}\text { Kondisi } & \\
\text { infrastruktur yang } & \text { kurang } \quad \text { baik } \\
\text { namun kondisi } & \text { kelentingan tinggi. }\end{array}$ \\
\hline
\end{tabular}

Tipologi $\mathrm{H}$ (Tertinggal-Resiliensi sedang)

Tipologi I (Tertinggal-Resiliensi rendah)

Arahan Rencana Pemanfaatan Dana Desa

Pemanfaatan Dana Desa bagi kegiatan pemberdayaan masyarakat di prioritaskan pada penegakan lumbung ekonomi desa, pengelolaan kesiapsiagaan menghadapai bencana alam serta kejadian luar biasa lainnya. Pengadaan, pembangunan dan pemeliharaan sarpras lingkungkungan untuk kesiapsiagaan menghadapi bencana alam, penanganan dan pelestarian lingkungan

Pemanfaatan Dana Desa bagi kegiatan pemberdayaan masyarakat di prioritaskan pada penegakan lumbung ekonomi desa, pelatihan kesiapsiagaan masyarakat dalam menghadapi bencana alam dan kejadian luar biasa lainnya. Pengadaan pembangunan dan pemeliharaan sarpras untuk penanggulangan bencana alam dan atau kejadian luar biasa

Memaksimalkan belanja Dana Desa bagi pemberdayaan masyarakat yang diprioritaskan untuk memperkuat lumbung ekonomi desa kebutuhan masyarakat desa, membuat kebijakan-kebijakan yang memfasilitasi pada upaya menjaga kelestarian alam.

Memaksimalkan belanja Dana Desa bagi pemberdayaan masyarakat yang diprioritaskan untuk memperkuat lumbung ekonomi desa, pengelolaan kesiapsiagaan menghadapai bencana alam serta kejadian luar biasa lainnya. Pengadaan, pembangunan dan pemeliharaan sarpras lingkungkungan untuk kesiapsiagaan menghadapi bencana alam, penanganan dan pelestarian lingkungan. Memaksimalkan belanja Dana Desa bagi pemberdayaan masyarakat yang diprioritaskan untuk memperkuat lumbung ekonomi desa, pelatihan kesiapsiagaan masyarakat dalam menghadapi bencana alam dan kejadian luar biasa lainnya. Pengadaan pembangunan dan pemeliharaan sarpras untuk penanggulangan bencana alam dan atau kejadian luar biasa

Pemanfaatan dana Desa bagi pembangunan dan intervensi pendidikan dan kesehatan (sanitasi dan air bersih), penguatan kelembagaan desa agar mampu lepas dari ketertinggalan, pemberdayaan masyarakat di prioritaskan untuk merintis lumbung ekonomi desa, membuat kebijakan-kebijakan yang memfasilitasi pada upaya menjaga kelestarian alam dan meredam pembangunan yang eksploitatif.

Kondisi infrastruktur yang pendidikan dan kesehatan (sanitasi dan air bersih), penguatan kurang baik kelembagaan desa agar mampu lepas dari ketertinggalan, dengan kondisi pemberdayaan masyarakat di prioritaskan untuk merintis lumbung kelentingan ekonomi desa, pengelolaan kesiapsiagaan menghadapai bencana sedang. $\quad$ alam serta kejadian luar biasa lainnya. Pengadaan, pembangunan dan pemeliharaan sarpras lingkungkungan untuk kesiapsiagaan menghadapi bencana alam, penanganan dan pelestarian lingkungan

Kondisi infrastruktur yang kurang baik dan kondisi kelentingan rendah.

Pemanfaatan dana Desa bagi pembangunan dan intervensi pendidikan dan kesehatan (sanitasi dan air bersih), penguatan kelembagaan desa agar mampu lepas dari ketertinggalan, pemberdayaan masyarakat di prioritaskan untuk merintis lumbung ekonomi desa, pelatihan kesiapsiagaan masyarakat dalam menghadapi bencana alam dan kejadian luar biasa lainnya. Pengadaan pembangunan dan pemeliharaan sarpras untuk penanggulangan bencana alam dan atau kejadian luar biasa

Kondisi

Tipologi J (Sangat TertinggalResiliensi tinggi)

infrastruktur yang sangat kurang, namun di sisi lain kondisi kelentingan tinggi. Memaksimalkan belanja dana desa bagi pembangunan dan intervensi pendidikan dan kesehatan (sanitasi dan air bersih) sehingga kebutuhan dasar masyarakat dapat terpenuhi, kegiatan pemberdayaan masyarakat di prioritaskan untuk merintis lumbung ekonomi desa dan peningkatan perekonomian lokal, membuat kebijakan-kebijakan yang memfasilitasi pada upaya menjaga kelestarian alam dan meredam pembangunan yang eksploitatif. Memaksimalkan belanja dana desa bagi pembangunan dan 


\begin{tabular}{lll}
\hline Tipologi Desa & Karakteristik & Arahan Rencana Pemanfaatan Dana Desa \\
\hline (Sangat Tertinggal- & infrastruktur yang & intervensi pendidikan dan kesehatan (sanitasi dan air bersih) \\
Resiliensi sedang) & $\begin{array}{l}\text { sangat kurang } \\
\text { dengan kondisi } \\
\text { kelentingan sedang }\end{array}$ & $\begin{array}{l}\text { pemberdayaan masyarakat di prioritaskan untuk merintis lumbung } \\
\text { ekonomi desa dan peningkatan perekonomian lokal, pengelolaan } \\
\text { kesiapsiagaan menghadapai bencana alam serta kejadian luar biasa }\end{array}$ \\
& & $\begin{array}{l}\text { lainnya. Pengadaan, pembangunan dan pemeliharaan sarpras } \\
\text { lingkungkungan untuk kesiapsiagaan menghadapi bencana alam, } \\
\text { penanganan dan pelestarian lingkungan }\end{array}$ \\
\hline
\end{tabular}

\section{KESIMPULAN}

Berdasarkan status pekembangannya desa - desa di kabupaten Pandeglang terdiri dari 4 tipe desa yaitu desa maju 5 desa, berkembang 92 desa, desa tertinggal 177 desa dan desa sangat tertinggal 52 desa. Berdasarkan status kelentingannya terdiri dari 71 desa dengan tingket kelentingan tinggi, 239 desa dengan tingkat tingkat kelentingan sedang, dan 16 desa dengan dengan kelentingan rendah, sedangkan berdasarkan status perkembangan dan kelentingan, desa di Pandeglang terdiri dari 10 tipe desa yang meliputi tipologi B (desa maju dengan kelentingan sedang), tipologi $C$ (desa maju dengan kelentingan rendah), tipologi $\mathrm{D}$ (desa berkembang dengan kelentingan tinggi), tipologi $\mathrm{E}$ (desa berkembang dengan kelentingan sedang), tipologi $F$ (desa berkembang dengan kelentingan rendah), tipologi $\mathrm{G}$ (desa tertinggal dengan kelentingan tinggi), tipologi $\mathrm{H}$ (desa tertinggal dengan kelentingan sedang), tipologi I (desa tertinggal dengan kelentingan rendah), tipologi J (desa sangat tertinggal dengan kelentingan tinggi) dan tipologi $\mathrm{K}$ (desa sangat tertinggal dengan kelentingan sedang). Pemanfaatan dana desa bagi perkembangan desa di Pandeglang dapat diarahkan sesuai dengan tipologi masing - masing desa dengan didasarkan pula pada permendesa no 19 tahun 2017 dan permendesa no 21 tahun tahun 2015, sehingga pemanfaatan dana desa dapat tepat sasaran dan bermanfaat bagi perkembangan dan kemajuan desa itu sendiri.

\section{DAFTAR PUSTAKA}

Artino A. 2017. Keterkaitan Dana Desa Terhadap Kemiskinan di Kabupaten Lombok Utara. Bogor (ID): Fakultas Ekonomi Managemen IPB.

Budiato T, Rustiadi E dan Dharmawan AH. 2017. Perkembangan dan Kemandirian Desa di Kabupaten Bogor Provinsi Jawa Barat. Jurnal Tata Loka. 19 (3): 230 - 241.

[BPS] Badan Pusat Statistik. 2018. Peraturan Kepala BPS No. 29 Tahun 2018 tentang Perubahan Peraturan Kepala BPS No. 55 Tahun 2017 tentang Kode dan Nama Wilayah Kerja Statistik Tahun 2017. Jakarta (ID): Badan Pusat Statistik

Hidayati IY dan Setyono JS. 2015. Tingkat Kerentanan Lingkungan Kabupaten Wonogiri. Jurnal Teknik PWK 4 (4): $592-604$.

Ihsan MM. 2015. Ketahanan Masyarakat Desa. Jakarta (ID): Kementerian Desa Pembangunan Daerah Tertinggal dan Transmigrasi.

Junaidi. 2012. Perkembangan Desa-desa Eks Transmigrasi dan Interaksi dengan Wilayah sekitarnya serta Kebijakan ke Depan [Disertasi]. Bogor (ID): Institut Pertanian Bogor.

[Kemendesa] Kementerian Desa Pembangunan Daerah Tertinggal dan Transmigrasi RI. 2015. Peraturan Menteri Desa No. 21 Tahun 2015 tentang Penetapan Prioritas Dana Desa Tahun 2016. Jakarta (ID): Kementerian Desa Pembangunan Daerah Tertinggal dan Transmigrasi RI.

[Kemendesa] Kementerian Desa Pembangunan Daerah Tertinggal dan Transmigrasi RI. 2017. Peraturan Menteri Desa No. 19 Tahun 2017 tentang Penetapan Prioritas Dana Desa Tahun 2018. Jakarta (ID): Kementerian Desa Pembangunan Daerah Tertinggal dan Transmigrasi RI.

[Kemen LHK] Kementerian Lingkungan Hidup dan Kehutanan RI. 2018. Peraturan Menteri LHK No. P.7/MENLHK/SETJEN/KUM.1/2/2018 tentang Pedoman Kajian Kerentanan, Risiko, Dan Dampak Perubahan Iklim. Jakarta (ID): Kementerian Lingkungan Hidup dan Kehutanan RI.

Rahayu SZ. 2015. Tipologi Desa Sebagai Dasar Penentu Prioritas Pembanguan di Kabupaten Pacitan [Tesis]. Yogyakarta (ID): Universitas Gadjah Mada 
Sartika C, Balaka MB dan Rumbia WA. 2016. Studi Faktor - faktor Penyebab Kemisminan Masyarakat Desa Lohia Kecamatan Lohia Kabupaten Muna. Jurnal Ekonomi (JE). 1 (1): 106 -118

Sidik F. 2015. Menggali Potensi Lokal Mewujudkan Kemandirian Desa. Jurnal Kebijakan dan Administrasi Publik 19 (2):115 - 131.

Syarief A, Sihombing M dan Tarmizi. 2014. Perkembangan Desa Mardinal I sebagai Daerah Hinterland Kota Medan (Studi Pendekatan dan Analisis Tipologi Desa). Jurnal Pendidikan Ilmu-Ilmu Sosial 6 (2): 1320.

Yoo G, Hadi S dan Kim AR. 2014. A Methodology to Assess Environmental Vulnerability in A Coastal City: Application to Jakarta, Indonesia. Ocean \& Coastal Management 102 (2014): 169-177.

Yudha EP. 2018. Implementasi Pengelolaan Keungan Desa dan Penaruhnya Terhadap Kinerja Pembangunan Perdesaan (Studi Kasus Kabupaten Pandeglang - Banten)[Disertasi]. Bogor (ID): Institut Pertanian Bogor.

Yuningsih NY dan Subekti VS. 2016. Demokrasi dalam Pemilihan Kepala Desa? Studi Kasus Desa Dengan Tipologi Tradisional, Transisional, dan Modern di Provinsi Jawa Barat Tahun 2008-2013. Jurnal Politik $1(2): 231-261$. 